\title{
Pemilihan Intervensi Ergonomi untuk Mengurangi Beban Kerja Mental pada Operator
}

\author{
Arnes Faradilla $^{1)}$, Janes Rivai ${ }^{2)}$, Dian Mardi Safitri ${ }^{3)}$ \\ Jurusan Teknik Industri, Fakultas Teknologi Industri, Universitas Trisakti \\ Jl. Kyai Tapa No.1, RT.6/RW.16, Tomang, Daerah Khusus Ibukota Jakarta 11440, Indonesia \\ E-Mail : arnes.faradilla@trisakti.ac.id ${ }^{1)}$, janes.nababan12@gmail.com ${ }^{2}$, dianmardi.safitri@gmail.com ${ }^{3)}$
}

\begin{abstract}
ABSTRAK
Beban kerja mental adalah proporsi keterbatasan operator untuk memperoleh informasi yang digunakan dalam melakukan pekerjaan. PT Batasasura merupakan salah satu manufaktur yang memproduksi filter, fuel tank dan radiator. Perusahaan ini memiliki permintaan yang tinggi setiap harinya dengan deadline yang sempit. Oleh karena itu, operator menjadi stres dan mengalami penurunan produktivitas. Tujuan penelitian ini adalah untuk mengidentifikasi beban kerja mental pada operator di filter manufacturing dan mengidentifikasi intervensi ergonomi yang sesuai untuk menurunkan beban kerja mental. Metode yang digunakan adalah NASA-TLX untuk mengukur beban kerja mental dan metode AHP untuk menentukan intervensi ergonomi. Hasil penelitian ini menunjukkan $75 \%$ operator mengalami beban mental yang tinggi. Hasil intervensi ergonomi yang terpilih untuk menurunkan beban kerja mental adalah aromaterapi.
\end{abstract}

Kata kunci: Beban Kerja Mental, NASA-TLX, AHP, Filter Manufacturing, Intervensi Ergonomi.

\section{Selection of Ergonomic Intervention to Decrease Mental Workload in Operator}

\section{ABSTRACT}

Mental workload is a limitation proportion of operator to get information that used to perform the task. PT Batarasura is one of the manufacture that produce filter, fuel tank and radiator. This company has high production to fulfill the high demand in a day. Therefore, It may cause the operators become stressfull and cause the low productivity. The purpose of this research is to identify the mental workload of operators in filter manufacturing and identify the suitable ergonomic intervension to decrease the mental workload. The method of this research is NASA-TLX to measure mental workload and AHP to determine the ergonomic intervension. The results of mental workload measurement is $75 \%$ operators has high mental workload. The result of ergonomic intervention selection is aromatheraphy.

Keywords: Mental workload, NASA-TLX, AHP, Filter Manufacture, Ergonomic Intervention.

\section{Pendahuluan}

Setiap perusahaan memiliki target produksi yang harus dicapai oleh seluruh karyawan dan memiliki tenggang waktu tertentu. Hal ini terkadang sering membuat karyawan menjadi stres dan mengakibatkan produktivitas menurun. Selain itu, beban kerja yang berlebihan dapat membuat karyawan menjadi cepat lelah sehingga sering kali menimbulkan cidera bahkan kecelakaan kerja. Menurut Munandar (2001), karakteristik pekerjaan adalah sebuah pekerjaan dapat melahirkan tiga keadaan psikologis dalam diri seorang karyawan yakni mengalami makna kerja, memikul tanggung jawab akan hasil kerja, dan pengetahuan akan hasil kerja. Menurut Rizqiansyah et al. (2017) secara spesifik, beban kerja dapat dibagi dua, yaitu beban kerja fisik dan mental. Beban mental memiliki resiko terhadap tingkat stres dari karyawan. Stres merupakan faktor fisik, dan emosional yang dapat menyebabkan tekanan pada mental (Zuraida \& Chie, 2013).

Perusahaan manufaktur merupakan perusahaan yang memiliki beban kerja tinggi. Manufaktur memiliki target pencapaian tinggi 
dan pekerjaan yang cenderung berat. PT. Batarasura Mulia merupakan salah satu perusahaan manufaktur yang memiliki target produksi yang tinggi. Produk yang dihasilkan pada perusahaan ini adalah filter, fuel tank dan radiator dengan beberapa lini produksi dalam proses produksi yaitu Filter Manufacturing, Radiator Assembly, dan Fuel Tank Assembly. Perusahaan ini memiliki sistem make to order dimana produk tersebut dibuat sesuai dengan permintaan konsumen. Oleh karena itu, sistem produksi diperusahaan ini memiliki waktu pemesanan yang tidak menentu dengan waktu produksi yang cukup singkat.

Data produksi selama 1 tahun terakhir menunjukkan adanya penurunan produksi sebesar $25 \%$ yang diakibatkan turunnya produktivitas operator. Hal ini menyebabkan perusahaan memperoleh komplen dari pelanggan. Tuntutan pekerjaan yang tinggi yaitu 1000 pcs sehari membuat karyawan mengalami tekanan kerja yang tinggi.

Menurut (Widyanti, Johnson \& Waard, 2010), beban kerja mental dapat diukur dengan pendekatan fisologis (karena terkuantifikasi dengan dengan kriteria obyektif, maka disebut metode obyektif). Pengukuran beban kerja mental sangat penting dilakukan untuk mendesain dan mengevaluasi sistem kerja yang diakibatkan oleh beban kerja tinggi, kelelahan dan menurunnya produktivitas kerja (Hertzum \& Holmegaard, 2013)

Kerja mental meliputi kerja otak dalam pengertian sempit dan pemrosesan informasi (Diniaty \& Ikhsan, 2018). Berdasarkan hasil observasi dan wawancara yang dilakukan kepada operator Filter Manufacturing, operator mengalami tekanan pekerjaan untuk memenuhi tingginya permintaan konsumen. Permintaan tersebut juga memiliki batas waktu yang beragam sehingga operator harus menyelesaikan sebelum batas waktu yang telah ditentukan. Menurut Hutagalung \& Gustomo (2013) informasi mengenai beban kerja karyawan sangat penting untuk mengetahui apakah operator memiliki beban pekerjaan yang berlebih atau tidak. Hal ini disebabkan, setiap orang memiliki perbedaan beban kerja mental yang dirasakan (Waard \& Eavans, 2014).

Henry (1998) mengatakan beban kerja mental adalah beban kerja yang merupakan selisih antara tuntutan beban kerja dari suatu tugasa dengan kapasitas maksumum beban mental seseorang dalam kondisi termotivasi. Berdasarkan latar belakang tersebut, perlu dilakukan penelitian untuk mengetahui beban kerja mental di perusahaan PT. Batarasura Mulia yang dapat menyebabkan kecelakaan kerja.

\section{Metodologi}

Penelitian ini dilakukan secara langsung di PT. Batarasura Mulia. Responden yang digunakan sebanyak 16 orang yang merupakan populasi dari operator Filter Manufacturing di PT. Batarasura Mulia. Metode yang digunakan untuk mengukur beban kerja mental adalah NASA-TX. Metode NASA-TLX memiliki 6 dimensi yaitu mental demand $(M D)$, physical demand $(P D)$, temporal demand (TD), performance $(O P)$, effort (EF) and frustration level (FR) (Prabaswari, Indrawati \& Pradipta, 2018).

Setiap dimensi memiliki tujuan pengukuran yang berbeda. MD mengukur seberapa besar beban mental dan perseptual yang dibutuhkan untuk melihat, mengingat dan mencari, PD mengukur seberapa banyak aktivitas fisik yang dibutuhkan seperti menarik dan mendorong. TD mengukur jumlah tekanan yang waktu ketika mengerjakan suatu pekerjaan, seperti cepat, lambat atau santai. OP mengukur seberapa berhasil seseorang dalam melakukan pekerjaan dan seberapa puas terhadap pekerjaannya tersebut. EF mengukur seberapa berat kerja mental dan fisik untuk melakukan pekerjaannya. FR mengukur tentang tingkat stres seseorang ketika melakukan pekerjaannya.

Menurut Hidayat et al. (2013) secara umum, untuk mengukur beban kerja mental adalah pembobotan hasil kuesioner, pemberian nilai atau skala, perhitungan WWL dan pengkategorian penilaian beban kerja. Langkah-langkah yang digunakan untuk 
mengukur beban kerja mental menggunakan metode NASA-TLX yaitu:

\section{Pembobotan}

Pada tahap ini, responden diminta untuk melingkari salah satu dari indikator yang paling dirasakan oleh operator dari masingmasing indikator. Tahapan ini membandingkan satu indikator dengan indikator lainnya, sehingga diperoleh 15 perbandingan berpasangan seperti yang ditunjukkan pada Tabel 1. Pembobotan dilakukan dengan melihat menurut subjek yang lebih dominan dalam pekerjaannya (Ramadhania \& Parwati, 2015).

\section{Pemberian Rating}

Tahapan ini responden diminta untuk memberikan rating terhadap 6 indikator beban kerja mental. Rating tersebut bersifat subyektif tergantung dari beban kerja mental yang dirasakan oleh responden tersebut.

\section{Perhitungan Nilai Produk}

Perhitungan nilai produk dilakukan dengan mengalikan nilai bobot dan rating dari setiap indikator.

4. Menghitung Nilai Weighted Workload (WWL)

Perhitungan WWL dilakukan dengan menjumlahkan semua hasil nilai produk dari semua indikator beban kerja mental.

5. Menghitung Rata-Rata WWL

Rata-rata WWL diperoleh dengan membagi nilai WWL dengan 15.

Tabel 1. Perbandingan Berpasangan

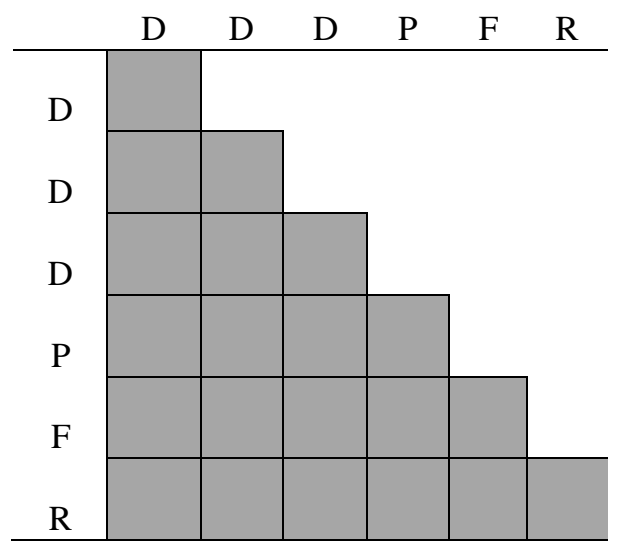

Setelah diperoleh nilai beban kerja mental, kemudian dilakukan pemilihan intervensi ergonomi menggunakan metode Analytic Hierarchy Process (AHP) untuk mengurangi beban kerja mental di departemen tersebut. AHP merupakan salah satu teknik pengambilan keputusan dengan beberapa kriteria yang menggabungkan antara kriteria secara kuantitatif dan kualitatif (Taherdoost, 2017).

Pemilihan alternatif intervensi ergonomi didasarkan oleh kriteria pendukung keputusan dalam penentuan alternatif yang sesuai dengan permasalahan yang terjadi pada lini produksi Filter Manufacturing.

Tahapan yang dilakukan pada metode AHP yaitu :

1. Identifikasi Pemilihan Intervensi Ergonomi

Tahapan ini melakukan identifikasi alternatif-alternatif yang digunakan untuk melakukan intervesi ergonomi dalam penurunan beban kerja mental. Setelah itu menentukan kriteria dari alternatif yang telah dipilih.

2. Penyusunan Hirarki dari Kriteria dan Alternatif

Tahapan selanjutnya adalah membuat hirarki dari kriteria dan alternatif yang digunakan untuk menunrunkan beban kerja mental pada operator.

3. Penilaian dan Pemeriksaan Konsistensi Matriks Berpasangan Kriteria

Tahapan ini dilakukan dengan membuat perbandingan berpasangan antar kriteria yang telah ditentukan sehingga diperoleh hasil bobot pada kriteria.

\section{Penentuan Prioritas}

Penentuan prioritas dapat dilakukan dengan perangkingan bobot setiap alternatif dan mengalikan setiap bobot alternatif dengan bobot kriteria.

5. Analisis Hasil Pengambil Keputusan

Penentuan hasil akhir dilihat dari nilai bobot tertinggi dari setiap alternatif. 


\section{Hasil dan Pembahasan}

\subsection{Karakteristik Responden}

Karakteristik responden yang diamati berdasarkan jenis kelamin dan usia operator kerja. Jenis kelamin dan usia operator dapat mempengaruhi proses produksi berdasarkan karakteristik pekerjaan tiap operator kerja. Hasil karakteristik responden berdasarkan jenis kelamin untuk responden operator yaitu 15 operator pria dan 1 operator wanita. Tabel 2 menunjukkan kategori usia operator pada Filter Manufacturing.

Tabel 2. Kategori Usia Operator Pada Filter

\begin{tabular}{ccc}
\multicolumn{3}{c}{ Manufacturing } \\
\hline No & Kategori Usia (Tahun) & Jumlah \\
\hline 1 & $21-30$ & 3 \\
2 & $31-40$ & 4 \\
3 & $41-50$ & 5 \\
4 & $\geq 50$ & 4 \\
\hline
\end{tabular}

Pada Tabel 2 terlihat bahwa jumlah paling banyak berada pada kategori usia 4150 tahun. Berdasarkan hasil tersebut, operator mayoritas berasal dari pria dengan rentang usia 41-50 tahun.

Karakteristik responden dalam pengambilan keputusan dengan metode Analytic Hierarchy Process (AHP) untuk penentuan bobot dan kriteria menggunakan kuesioner yaitu Departement Section Head Engineering dan Departement Section Head Filter Manufacturing pada PT. Batarasura Mulia.

\subsection{Perhitugan Metode NASA-TLX}

Pengukuran beban kerja mental menggunakan NASA-TLX dilakukan dengan beberapa tahapan yaitu pembobotan, pemberian rating, perhitungan nilai produk, perhitungan WWL. Output yang dihasilkan dari pengukuran ini berupa tingkat beban kerja mental yang dialami setiap operator Filter Manufacturing. Tabel 3 merupakan hasil dari WWL pada 16 operator.

Hasil pengukuran beban kerja mental menggunakan metode NASA-TLX, diketahui bahwa hasil beban kerja mental berdasarkan 16 operator Filter Manufacturing memiliki 107 beban kerja mental dengan level kriteria yang sedang, tinggi, dan sangat tinggi.

\begin{tabular}{|c|c|c|}
\hline Operator & WWL & Level Kriteria \\
\hline 1 & 68,33 & Tinggi \\
\hline 2 & 54,67 & Sedang \\
\hline 3 & 68,00 & Tinggi \\
\hline 4 & 69,33 & Tinggi \\
\hline 5 & 67,33 & Tinggi \\
\hline 6 & 84,33 & Sangat Tinggi \\
\hline 7 & 58,67 & Sedang \\
\hline 8 & 64,33 & Tinggi \\
\hline 9 & 46,67 & Sedang \\
\hline 10 & 68,33 & Tinggi \\
\hline 11 & 45,00 & Sedang \\
\hline 12 & 75,00 & Tinggi \\
\hline 13 & 70,00 & Tinggi \\
\hline 14 & 80,67 & Sangat Tinggi \\
\hline 15 & 84,33 & Sangat Tinggi \\
\hline 16 & 81,33 & Sangat Tinggi \\
\hline
\end{tabular}

Tabel 3 menunjukkan terdapat 4 operator yang mengalami beban kerja mental dengan level kriteria sedang, kemudian terdapat 8 operator yang mengalami beban kerja mental dengan level kriteria tinggi. Untuk level kriteria beban kerja mental yang dikategorikan sangat tinggi dialami oleh 4 operator kerja.

Hasil rata-rata pengukuran beban kerja mental untuk 16 operator sebesar 67,9 yaitu termasuk kategori tinggi. Berdasarkan hasil pengukuran tersebut, diperlukan intervensi ergonomi untuk mengurangi beban kerja mental pada operator Filter Manufacturing.

\subsection{Pengambilan Keputusan Menggunakan Menggunakan Metode Analytic Hierarchy Process (AHP)}

Hasil NASA-TLX menjukkan beban
kerja mental pada operator Filter
Manufacturing masuk kedalam kategori
tinggi. Berdasarkan hasil wawancara dan
pengamatan, pemilihan penerapan intervensi
ergonomi yang berpengaruh untuk
mengurangi beban kerja mental operator
adalah terapi musik, aromaterapi, pijat


refleksi dan meditasi. Menurut Sasongko, et al. (2017) prinsip AHP adalah dengan menyederhanakan suatu persoalan kompleks yang tidak terstruktur dan dinamik, serta menatanta dalam bentuk hirarki.

Pemilihan penerapan intervensi ergonomi tersebut kemudian dijadikan alternatif-alternatif dalam mengurangi tingkat beban kerja yang dialami operator Filter Manufacturing. Kriteria penilaian terhadap pemilihan penerapan intervensi ergonomi tersebut adalah biaya, alat penunjang, kualitas, dan efektivitas. Masalah multi criteria decision making (MCDM), pengambil keputusan menilai sekumpulan alternatif keputusan berdasarkan kriteria (Kadarsyah, 1998).

Setelah ditentukan alternatif-alternatif yang dapat dilakukan, maka penentuan kriteria agar alternatif yang nantinya akan dilakukan menjadi sesuai. Berdasarkan Hasil diskusi dengan orang yang sama, diketahui empat kriteria penentuan intervensi ergonomi dilakukan sehingga diketahui hasil pertimbangan pemilihan alternatif dalam intervensi ergonomi yaitu biaya, alat penunjang, kualitas, dan efektivitas.

Biaya berhubungan dengan apakah alternatif tersebut memiliki biaya yang rendah atau tidak, alat penunjang berkaitan dengan apakah alternatif tersebut memerlukan alat penunjang seperti lilin aroma terapi, kualitas berkaitan dengan apakah alternatif tersebut memiliki kualitas yang baik atau tidak, sedangkan efektivitas berkaitan dengan seberapa efektif alternatif tersebut diaplikasikan untuk menurunkan beban kerja mental.

Setelah membentuk struktur hierarki, langkah berikutnya adalah membuat perbandingan berpasangan antar kriteria sehingga diperoleh hasil bobot pada kriteria. Penentuan bobot kriteria dilakukan dengan pengisian kuesioner oleh Departement Section Head Engineering selaku responden pakar pertama dan Departement Section Head Filter Manufacturing selaku responden pakar kedua. Pengisian bobot kriteria dilakukan berdasarkan ketentuan pada skala perbandingan oleh Saaty.

Setelah mengetahui bobot prioritas berdasarkan kriteria selanjutnya melakukan perhitungan matriks berpasangan pada setiap alternatif berdasarkan kriteria.

Tahapan perhitungan matriks berpasangan pada setiap alternatif berdasarkan kriteria yang sama dengan tahapan sebelumnya untuk mengetahui bobot prioritas dari setiap alternatif.

Tabel 4. Perhitungan Bobot Prioritas Kriteria Dari Segi Biaya

\begin{tabular}{ccccccc}
\hline Alternatif & $\begin{array}{c}\text { Terapi } \\
\text { Musik }\end{array}$ & $\begin{array}{c}\text { Aroma } \\
\text { Terapi }\end{array}$ & $\begin{array}{c}\text { Pijat } \\
\text { Refleksi }\end{array}$ & Meditasi & Jumlah & Prioritas \\
\hline Terapi Musik & 0,20 & 0,19 & 0,20 & 0,24 & 0,83 & 0,21 \\
Aromaterapi & 0,50 & 0,47 & 0,51 & 0,36 & 1,82 & 0,46 \\
Pijat Refleksi & 0,20 & 0,19 & 0,21 & 0,29 & 0,89 & 0,22 \\
Meditasi & 0,10 & 0,15 & 0,08 & 0,12 & 0,46 & 0,11 \\
\hline
\end{tabular}

Tabel 5. Perhitungan Bobot Prioritas Kriteria Dari Segi Alat Penunjang

\begin{tabular}{ccccccc}
\hline Alternatif & $\begin{array}{c}\text { Terapi } \\
\text { Musik }\end{array}$ & $\begin{array}{c}\text { Aroma } \\
\text { Terapi }\end{array}$ & $\begin{array}{c}\text { Pijat } \\
\text { Refleksi }\end{array}$ & Meditasi & Jumlah & Prioritas \\
\hline Terapi Musik & 0,31 & 0,26 & 0,47 & 0,26 & 1,30 & 0,32 \\
Aromaterapi & 0,44 & 0,36 & 0,27 & 0,32 & 1,39 & 0,35 \\
Pijat Refleksi & 0,13 & 0,26 & 0,19 & 0,32 & 0,90 & 0,22 \\
Meditasi & 0,13 & 0,12 & 0,06 & 0,11 & 0,42 & 0,10 \\
\hline
\end{tabular}


Tabel 6. Perhitungan Bobot Prioritas Kriteria Dari Segi Kualitas

\begin{tabular}{ccccccc}
\hline Alternatif & $\begin{array}{c}\text { Terapi } \\
\text { Musik }\end{array}$ & $\begin{array}{c}\text { Aroma } \\
\text { Terapi }\end{array}$ & $\begin{array}{c}\text { Pijat } \\
\text { Refleksi }\end{array}$ & Meditasi & Jumlah & Prioritas \\
\hline Terapi Musik & 0,21 & 0,15 & 0,34 & 0,29 & 0,97 & 0,24 \\
Aromaterapi & 0,50 & 0,35 & 0,34 & 0,29 & 1,48 & 0,37 \\
Pijat Refleksi & 0,08 & 0,15 & 0,14 & 0,14 & 0,51 & 0,13 \\
Meditasi & 0,21 & 0,35 & 0,19 & 0,29 & 1,04 & 0,26 \\
\hline
\end{tabular}

Tabel 7. Perhitungan Bobot Prioritas Kriteria Dari Segi Efektivitas

\begin{tabular}{ccccccc}
\hline Alternatif & $\begin{array}{c}\text { Terapi } \\
\text { Musik }\end{array}$ & $\begin{array}{c}\text { Aroma } \\
\text { Terapi }\end{array}$ & $\begin{array}{c}\text { Pijat } \\
\text { Refleksi }\end{array}$ & Meditasi & Jumlah & Prioritas \\
\hline Terapi Musik & 0,27 & 0,29 & 0,21 & 0,22 & 0,99 & 0,25 \\
Aromaterapi & 0,27 & 0,29 & 0,36 & 0,44 & 1,36 & 0,34 \\
Pijat Refleksi & 0,19 & 0,12 & 0,15 & 0,11 & 0,57 & 0,14 \\
Meditasi & 0,27 & 0,29 & 0,29 & 0,22 & 1,08 & 0,27 \\
\hline
\end{tabular}

Tabel 8. Ranking Bobot Alternatif Terpilih

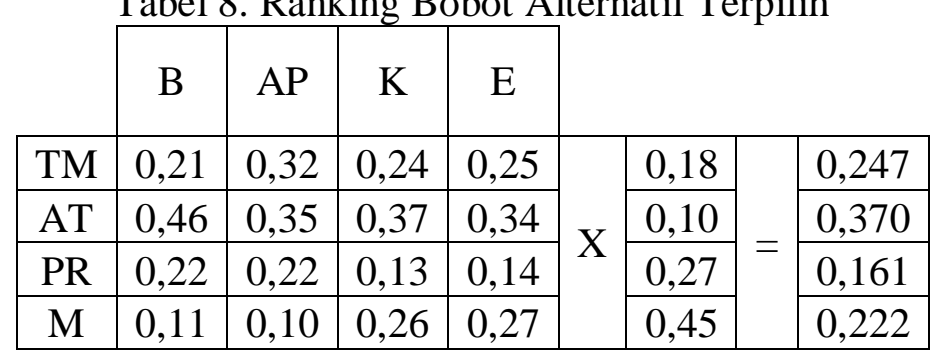

Tahap terakhir dari perhitungan Analytic Hierarchy Process (AHP) ini adalah dengan menentukan prioritas dari alternatif-alternatif pemilihan intervensi ergonomi. Perhitungan prioritas dapat dilakukan dengan perangkingan bobot setiap alternatif dan mengalikan setiap bobot alternatif dengan bobot kriteria.

Penentuan prioritas diketahui berdasarkan hasil pengalian prioritas pada kriteria dan prioritas alternatif dalam pengambilan keputusan. Hasil tersebut menjadi akhir keputusan intervensi ergonomi yang akan dipilih perusahaan untuk mengurangi beban kerja mental pada karyawan.

Alternatif yang digunakan adalah Terapi Musik (TM), Aromaterapi (AT), Pijat Relfeksi (PR), Meditasi (M). Kriteria yang digunakan adalah Biaya (B), Alat Penunjang (AP), Kualitas (K), dan Efektivitas (E). Tabel 8 menunjukkan ranking bobot alternatif terpilih.
Tabel 8 menunjukkan rangking bobot alternatif terpilih. Berdasarkan hasil tersebut, diperoleh bahwa aromaterapi sebagai intervensi ergonomi terpilih pada operator Filter Manufacturing dengan nilai 0,37.

Aromaterapi khususnya lavender merupakan tindakan terapiutik yang bermanfaat meningkatkan keadaan fisik dan psikologis menjadi lebih baik (Widyastuti, 2013). Selain itu, aromaterapi lavender dapat meningkatkan kualitas tidur, menurunkan kecemasan dan beban mental seseorang (Sari \& Leonard, 2018).

\section{Kesimpulan dan Saran}

\subsection{Kesimpulan}

Berdasarkan hasil penelitian diperoleh kesimpulan yaitu:

1. Operator Filter Manufacturing memiliki beban kerja mental tinggi sebesar 67,9.

2. Terapi yang terpilih berdasarkan hasil perhitungan metode AHP adalah aromaterapi.

\subsection{Saran}


Saran yang dapat diberikan untuk mengurangi beban kerja mental adalah mempertimbangkan kembali beban kerja operator. Hal ini dapat dilakukan dengan memberikan tambahan jam istirahat dan mengadakan rotasi kerja kepada operator agar beban kerja dapat merata. Menurut Salsia et al. (2018) pengaturan waktu istirahat harus disesuaikan dengan sifat, jenis pekerjaan dan faktor lingkungan yang mempengaruhinya seperti lingkungan kerja panas, dingin, bising dan berdebu.

\section{Daftar Pustaka}

Henry, R. J. (1988). Human Mental Workload. New York, USA: Elsevier Science Publisher B.V

Hertzum, M., \& Holmegaard, K, D. (2013). Perceived Time As A Measure of Mental Workload: Effects of Time Constraints and Task Success. International Journal of Human-Computer Interaction Taylor and Francis, Vol. 29, 26-39.

Hidayat T. F., Pujangkoro S., \& Anizar. (2013). Pengukuran Beban Kerja Perawat Dengan Menggunakan Metode NASATLX Dirumah Sakit XYZ. e-Jurnal Teknik Industri FT USU, Vol. 2, 42-47.

Hutagalung, R., \& Gustomo, A. (2013). Workload Analysis For Planning Needs of Employees In The Corporate Administration Unit PT Timah (Persero) Tbk. The Indonesian Journal of Business Administration, Vol. 2, 2290-2297.

Kadarsyah. (1998). Sistem Pengambilan Keputusan: Suatu Wacana Struktural Idealisasi Dan Implementasi Konsep Pengambilan Keputusan. Edisi 1. Bandung: PT. Remaja Rosdakarya.

Prabaswari, A. D., Indrawati, S. \& Pradipta, T. (2018). The mental workload analysis of safety workers in an Indonesian oil mining industry. ICET4SD 2017, MATEC Web of Conferences.

Ramadhania, N., \& Parwati, N. (2015). Pengukuran Beban Kerja Psikologis Karyawan Call Center Menggunakan Akan Metode NASA-TLX (Task Load Index) Pada PT. XYZ. Seminar Nasional
Sains dan Teknologi, Fakultas Teknik Universitas Muhammadiyah Jakarta.

Rizqiansyah, M. Z. A., Hanurawwan. F. \& Setiyowati, N. (2017). Hubungan Antara Beban Kerja Fisik dan Beban Kerja Mental Berbasis Ergonomi Terhadap Tingkat Kejenuhan Kerja Pada Karyawan PT Jasa Marga (Persero) Tbk Cabang Surabaya Gempol. Jurnal Sains Psikologi, Vol. 1, 37-42.

Salsia, K., Safitri, D, M., \& Anggarini, R. (2018). Intervensi Ergonomi Untuk Menurunkan Beban Kerja Pada Operator Lantai Produksi Bisnis Unit South Copper Rod. Jurnal Teknik Industri, Vol. 18, 34-42.

Sari, D., \& Leonard, D. (2018). Pengaruh Aroma Terapi Lavender Tehadap Kualitas Tidur Lansia Di Wisma Cinta Kasih. Jurnal Endurance, Vol. 3, 121130.

Sasongko, A., Astuti, E, F., \& Maharani, S. (2017). Pemilihan Karyawan Baru Dengan Metode AHP (Analytic Hierarchy Process). Jurnal Informatika Mulawarman, Vol. 12.

Taherdoost, H. (2017). Decision Making Using the Analytic Hierarchy Process (AHP). International Journal of Economics and Management System, Vol. 2, 244-246

Waard, D., \& Evaans, B. L. (2014). Selfreport Scales Alone Cannot Capture Mental Workload. Cogn Tech WorkSpinger, Vol. 16, 303-305.

Widyanti, A., Johnson, A. \& Waard, D.d (2010). Pengukuran Beban Kerja Mental Dalam Searching Task Dengan Metode Rating Scale Mental Effort (RSME). JATI Universitas Diponegoro, Vol. 5.

Widyastuti, Y. (2013). Efektivitas Aromaterapi Lavender Dalam Menurunkan Nyeri dan Kecemasan pada pasien Pre Operasi Fraktur Femur di RS Ortopedi Prof. DR. R. Soeharso Surakarta. Prosiding Konferensi Nasional PPNI Jawa Tengah 2013, 9294.

Zuraida, R., \& Chie, H, H. (2013). Skala Pengukuran Shift Kerja, Beban Kerja dan 
Teknoin Vol. 25, No. 2, September 2019: 104-111

Persepsi Kesehatan Sebagai Stressor Dengan Fasilitas Manajemen Untuk Penanggulangannya. Industrial And System Engineering Assessment Journal, Vol.14, 15-21. 